Special Topic

\title{
The Role of Informal Organizations in Resettlement Adjustment Process: A Case Study of Iqubs, Idirs and Mahabers in the Ethiopian Community in Toronto
}

\author{
Getachew Mequanent
}

\section{Précis}

Cette étude examine le rôle des trois genres d'organisation sociale informelle dans le processus d'adaptation des réfugiés éthiopiens insérés à Toronto et à Ottawa. Ce sont l'iqub (caisse populaire), le mahaber (réseau social) et 1'idir (assurance), dont la plupart rétablit l'héritage chrétien du pays d'origine. Pour pistonner l'entrée de leurs compatriotes dans des petites entreprises, l'iqub regroupe de huit á dix membres qui circulent mensuellement $l^{\prime}$ ensemble de leurs contributions d'argent $l^{\prime} u n$ à l'autre jusqu'au dernier gagnant. Entre-temps, les membres développent une solidarité qui les englobe et qui projète au delà du but originel. Quant au second, douze membres assemblent pour la mahaber, comme commémoraison des apôtres, pour renforcer le sens d'ensemble et d'assistance mutuelle et financière. Chaque membre a tour de rôle invite ses camarades chez lui/elle pour célébrer une occasion religieuse. À travers quelques années le réseau continu fait accroître cette solidarité sociale. Troisièmement, quelques vingt membres de l'idir contribuent une somme comme placement commun. Pendant d'une cérémonie funéraire ou autre rite de passage, le comité exécutif de l'idir assigne un montant au contribuable-impliqué pour défrayer les coûts élevés. Ces occasions renforcent l'interdépendance des membres ainsique la structure organisationnelle. En somme, par l'activité socioémotionnelle, ces trois formes avancent l'intégration sociale des membres dans le pays d'accueil.

Getachew Mequanent formerly a researcher at the Centre for Refugee Studies, York University, is presently following his graduate program in Environmental Studies at Carlton University, Ottawa.
This study assesses the role of informal organizations in the immigrant/refugee adjustment process-those organizations that exist outside of mainstream institutions and structures. The study is based on the case study of iqubs ("credit union"), idirs ("insurance"), and mahabers ("social network") in the Ethiopian communities in Toronto and Ottawa, more specifically that in the Christian religious background. As recent arrivals, Ethiopians face social, occupational and cultural barriers to obtaining the means of sustaining life in Canada. Examples include being unable to have secured sources of livelihoods, $a$ "roof over the head," insurance policy, access to institutions and facilities and possession of assets which guarantee independence and dignity in life. The introduction of cultural practices such as iqubs, idirs, and mahabers therefore, has become necessary to pull individual Ethiopians' efforts together: iqubs help mobilize financial resources; idirs help cover costs incurred during a funeral and other emergency situations, and as such, are insurance organizations; mahabers bring Ethiopians together each month and satisfy the spiritual and social aspects of life.

Despite variations in their functions, idirs, mahabers and iqubs have a similar social, philosophical or moral foundation. This foundation is the Ethiopian mahaber tradition. A mahaber might be a religious association, but it has also philosophical and moral core value that denotes the idea of solidarity or mutual support. In the countryside, for example, farmers use a system (of debo or webera) to work together on crop fields during ploughing and harvesting season. Through such a system farmers also help those who fall sick during a planting or harvesting sea- son. Sentiments like "sharing experiences in times of joy and sadness" constitute the most important aspect in Ethiopian culture.

This study examines how mahabers, idirs and iqubs help Ethiopians to adjust to the Canadian society. It also examines whether they are flexible and adaptable organizations, in light of the fact that immigrant/refugee adaptation and integration is a process of change and continuity in individual behaviour and values.

\section{Crafting 'Safety Net" Strategies? \\ The Role of Iqubs, Mahabers, and Idirs}

Experience shows that if the process of learning and adapting to "living" in a new environment becomes difficult, immigrants/refugees turn to families, friends and group networks for support. For instance, mutual associations were instrumental in the provision of support for Southeast Asian refugees in Canada, France and the United States in their early "resocializing process" (Lanphier 1984). Thomas and Znaniecki's (1958) comprehensive study of Polish immigrants in America in the 1950s shows how self-help parish associations came to flourish in settlement areas, and how these associations later became transformed into larger institutions encompassing many settler communities. Traditional support systems have also gained popularity among the Somali community due to enduring poverty (OpokuDapaah 1993). For instance, "grouptenancy" among the Somalis became an option not so much for the desire to live together as for their lack of adequate income to find affordable housing. However, this led to the revival of Somalian traditions such as the revitalizing of family values, strengthening 
kinship ties, and strict observation of Islamic rules.

Inadequate attention is paid to informal networks of resource exchange among immigrants and refugees. From a conventional point of view, informal organizations such as those found in the Ethiopian community in Toronto are said to be "backward" and unproductive, for no other reason than the lack of mechanical (top-down) command structure and systematic management of organizations. Perception and attitudes such as this have always led decision makers to overlook the viability of grassroot-based organizations as an effective support system in times of difficult social and economic conditions.

Informal social organizations often consist of people who share the same sentiments and perspectives on the made in the event setting and are action oriented (Levy 1969). Their organizational structure is simple and less complex, making management of affairs compatible with the social and occupational requirements of members.

In his classical work of The Division of Labour in Society, Emile Durkheim had called this type of social organization a "mechanical solidarity," a process motored by the willingness of "similar" individuals to engage in a spirit of cooperation. In Canada, however, social organizations of such nature are understood to be intermingled with an "ethnic identity," a concept which refers to a group of people who are from a specific geographical area and who have racial roots and religious/cultural belief systems and practices different than the main-

\section{Despite variations in their functions, idirs, mahabers and iqubs have a similar social, philosophical or moral foundation. This foundation is the Ethiopian mahaber tradition. A mahaber might be a religious association, but it has also philosophical and moral core value that denotes the idea of solidarity or mutual support.}

basis of common national origin, philosophical and religious beliefs, friendship and family ties. They differ in size, capacity and in their purpose of existence. For example, some organizations can have as many as forty members while others only consist of five people. Moreover, there are organizations that serve the purpose of mutual aid or organizations that serve the individual best with the purpose of re-asserting his or her identity. Their existence can be temporary, ceasing to exist when the purpose that led to their formation declines in importance, or permanent if the importance of their purpose increases overtime. Furthermore, in the informal organizational setting face-to-face interaction is the normal routine of communication. As a result, members are able to influence each other and to have increased knowledge of conditions in the group. The organizational environment is more participatory. Decisions are stream society. Thus, according to Isajiw (1990), an "ethnic identity" by itself helps individuals to act together as a cohesive social unit and overcome difficulties. For example, when a person identifies with a certain ethnic group individual problems are transformed into collective concern, thereby paving the way for organized action. Secondly, identity is a subjective phenomenon and as such "gives individuals a sense of belonging and to the community a sense of oneness and historical meaning" (Isajiw 1990, p. $35)$, thereby providing a framework to construct a meaning out of past and present experiences and develop a collective vision of what life at present is and what it should be in the future. Be that as it may, the role of ethnic identity as an objective instrument to stimulate a process for organized action depends on the kind of relationship exhibited between a certain ethnic group and the wider Canadian society.
For example, Chinese and West Indians would retain their identity more than the Germans and Ukrainians, for obvious reason that the latter, because of the similarity of their ethnic backgrounds, encounter no serious problems of integrating into the wider Canadian society (Isajiw 1990).

Therefore, by identifying with their own "ethnic groups," newcomers such as Ethiopians not only attain a sense of belonging, but are also able to craft social and economic safety nets that provide alternative support systems. Yet, this by no means be viewed as a regressive change in individual attitude and perceptions. In fact, individuals who enter another "human ecology" are more likely to get acquainted with new values and often to critically question the viability of their old values and assumption (Hawley 1950). The tendency to criticize the "self" emanates from the individuals' struggle to adapt new attitudes and practices, so as to establish a "viable relationship" with the new environment. For example, new attitudes and patterns of interaction are needed to participate in the labour market and to "fit" into the technological and institutional environment. Hence, regardless of the intensity and magnitude of problems encountered during the adjustment process, immigrants/refugees would retain and nurture useful values and nullify unwanted ones.

The purposes driving the formation of organizations may vary within each ethnic group as well as from one group of individuals to another. For example, ethnic social clubs strive to aggregate leisure, while a mutual aid organization's formation is driven by desperate situations. In particular, desperate situations are an important aspect in many immigrant's / refugee's lives. Such newcomers leave their country because of the circumstances beyond their control and they attempt to adjust to the Canadian society without any material and social basis. Organizational goals and objectives, therefore, aim at responding to adjustment needs. The following section provides case studies to show how informal or- 
ganizations in the Ethiopian community in Toronto are helping Ethiopians to adjust to the Canadian socio-economic and cultural environment.

Naturally, there are many informal organizations in the Ethiopian community, ranging from unorganized groups such as friendship and family circles to the ones that are well organized. For the purpose of this study three iqubs (two of which are in Ottawa), two mahabers and an idir will be discussed. In referring to iqubs in Ottawa, the name of a member (the first contact person) will be used to distinguish them from each other; hence, they have been labelled as Adamu's $i q u b$ and Tadesse's iqub. In the same manner, the name of the mahabers are Wegayehu's mahaber and Desta's mahaber, and the name of the idir is the Wello idir.

\section{Background}

Iqubs, idirs, and mahabers in the Ethiopian community in Toronto are grassroots organizations created in response to the need for a social and economic "safety net" in Canadian society. To better understand how Ethiopian culture is being transplanted in the Canadian society and sustains these organization formations, it is helpful to look at them in the Ethiopian socioeconomic context.

\section{Iqubs 'Credit Union'}

In a country such as Ethiopia most people do not rely on banks for loans to start entrepreneurial activity or to buy a house. Because of high interest rates and the problem of meeting banks' collateral requirements many Ethiopians are not eligible for loans. For this reason people opt to form their own group, an iqub, and try to pull their financial resources together. Each member pays a fixed sum of money to the iqub every week or month, which is then allocated to members on rotating basis.

According to Donald Levine (1965) iqubs were first started by the Guraghe people, one of the many nationalities in Ethiopia, in the 1930s. Iqubs are most suited to business people, who wish to start a new enterprise, overcome cash flow shortages in their business, or import capital goods. Although contractual agreements regarding the method of payment and the amount of contributions are common, mutual trust is central to all forms of transactions.

The initiative to establish an $i q u b$ is often undertaken by two or three individuals. They meet and discuss rules and regulations, the amount of contributions which are affordable to wouldbe members and the frequency of payment. These individuals share their proposed idea with others. A dagna or president is elected. A date and time is set. On the first gathering each member is asked to present a wase, guarantor, who would be responsible for repaying the debt should a member default. After each member pays the money, the sum is given to a person who wins the ita or lottery. A member who receives the ita will not compete in another round in future but continues to pay his or her obligations. In situations where a person has an emergency need, he/she can buy the ita from another members. There is no fixed purchase rate but it could amount to one to three percent of the ita money. Again, a member who sells the ita is not eligible for future ita competition. After the last person receives the ita, another round resumes or the group get dissolved.

Three important elements of $i q u b$ that hold members together are membership criteria, mutual obligation and trust.

Membership Criteria: Membership in iqubs has two distinctive features. The first feature is that people must be at the same income level. For example, there are iqubs of rich merchants, those of government employees and pettytraders in the informal sector. Hence, merchants hold an ita of up to Birr 100,000 (US\$25,000), while petty-traders may arrange an ita of up to Birr 10,000 . The second characteristic is that iqubs require a voluntary association. This form of association is induced by a desire to gain benefits (loans) by becoming an iqub member; to participate in iqubs not so much due to encountering financial difficulties as for the sake of helping others; and to remain within a social circle, thereby to maintain such social relationships as family ties or friendship.

Mutual obligation and trust: In traditional a setting, lending money to a friend or a family member is quite common, but the rate of default for such arrangement is often higher. Part of this is that a borrower is often unable to repay. Another reason is that there are insufficient pressures for the borrower to accumulate enough savings, particularly if one takes account of the social stigma attached to taking a member of a family or a friend to court to force him/her to pay. By contrast, $i q u b$ agreements dictate that all dues be paid on time and that even those who arrive late when itas are held pay fines. Such mutually agreed sanctions ensure that each member saves enough for the ita both to repay one's debt and to contribute towards keeping the ita balance steady. The presence of commonly agreed sanctions also increases members confidence to put their money in the rotating scheme of ita. The principle of trust brings the sociocultural aspect of $i q u b$ organizations into light.

Case Studies: Hassen's iqub has 15 members. The weekly ita is $\$ 1,650$, with each member contributing $\$ 110$. Hirut's iqub has 12 members and contribute $\$ 600$ each month to the ita which is worth $\$ 4800$. Each of the two iqubs in Ottawa consist of 20 members. The monthly ita in Tadesse's iqub amounts to $\$ 20,000$, with member contribution of $\$ 1,000$ each month. Adamu's iqub, however, has two kinds of itas. One ita is called a full-ita and requires members to pay $\$ 400$ every month or $\$ 200$ every two weeks. The second ita is called half-ita, for those members who can not afford to pay $\$ 400$ every month, and they pay $\$ 200$ every month or $\$ 100$ every two weeks. Both itas are drawn once a month and amounts to $\$ 4000$ for full-ita and $\$ 2000$ for half-ita.

In many cases iqubs dissolve following the end of the ita round. For exam- 
ple, the Toronto iqub finished its round arrange a new round many of the members were not interested; as a result the iqub dissolved. Although the ita money is very helpful to overcome financial problems, uncertainties about the ability to repay and the social pressure not to default payments can create a tremendous degree of anxiety for members, particularly for those who have no secured source of income. On this basis iqubs can be said to be a short term phenomenon. Yet, in other cases a new round of ita is arranged. For instance, Adamu and Tadesse's iqubs in Ottawa have already begun a new round.

Because rules and regulations are not made in due formal legal process and because iqubs cannot resolve disin May. When the chairman tried to

Members of iqubs often attempt to save part of their wage earnings by becoming an iqub member. In particular, this is very important for those who run their own taxi business and who get paid cash for their services. Members like Ambachew have been able to buy a "license plate" and run their own taxibusiness. Ambachew himself used the ita cash money to buy a vehicle at an auction for almost fifty-percent less than the price from the car dealers. An $i q u b$ has also helped Tadesse to start a taxi and a restaurant business. Some members in his iqub had also been able to use the ita money for down payment of a mortgaged house. At the later stage these mortgage holder would use the ita money to renegotiate mortgage payments with banks by reducing the outstanding balance by a lump

Iqubs, idirs, and mahabers in the Ethiopian community in Toronto are grassroots organizations created in response to the need for a social and economic "safety net" in Canadian society.

putes through court procedures, members always stress the importance of mutual trust and friendship. The centrality of trust in iqubs then gives rise to the need to screen out new members. New members are first introduced by an iqub member and their admission requires unanimous consent. The most important task is studying the background of a person such as sources of income and present and past social relations with others. Should members feel that the person is not trustworthy he/she will be told to take the ita only in the last round.

Yet, there is no evidence of defaulting let alone disappearing without repaying. In a situation where a person defaults due to circumstances beyond his or her control (layoffs, bankruptcy, for example), he/she will not be pressured to repay. For instance, one of the a member in Adamu's iqub in Ottawa used to own a restaurant business. When he declared bankruptcy members were left with no choice but to understand his critical situation. They used $i q u b^{\prime} s$ "reserve money" i.e., income derived from fines, etc., to pay for all his ita obligations. sum. For other members the iqub helped them to pay for car insurance, meet familial obligations-such as sending money home, buy furniture, prepare wedding, and travel.

Even though many perceive that iqubs are a short term phenomena, many more also attach a long term importance to the continuity of their functions. First, iqub provide individuals, particularly those who own a business and who are in debt (mortgaged house, for example), with a financial safety net. For example, if a taxi breaks down, the owner can always go to the $i q u b$ and request for the it $a$ to help cover the cost of repair; it will cost him nothing except a $\$ 50$ charge for the privilege of getting the money without waiting for his turn. Another example is wanting to fly to Ethiopia or somewhere else in emergency situations. If this happens the chairman of the iqub of the ita money within twenty-four hours. In Hassen Osman's case, for example, iqub had finished its round in May and was then dissolved. But in October Hassen heard some bad news: one of his friends who lives in Washcan phone people and raise at least half ington had been admitted to hospital. He then immediately phoned his former $i q u b$ members and was able to raise $\$ 2,000$; this incident reactivated the iqub and a new ita round then began. If a member does not have money at hand during such emergency situations he/she can always borrow from one of his or her fellow members.

Finally, iqubs play a crucial role in the social life of individual members. For instance, members highly value the sense of belonging to this form of social group and getting together each week or month to engage with friends. Iqubs also intervene to resolve family disputes and disputes among members.

\section{Mahabers ("Social Network")}

Mahabers are religious associations devoted to honouring a Saint for whom the group is named. The two mahabers are hosted on the 29th of each month (21st in Julian or Ethiopian calendar) to honour Kidist Mariam (St. Mary). Mahabers are associations organized around people who live in the same area. Hence, a religious mahaber is devoted to honouring a saint. The former Marxist-Leninist military regime created the Gebere mahabers (Peasants Association) to help implement the land reform and to perform administrative and policing tasks in the area. There were also meredaja mahabers organized for the purpose of helping each other, or to raise funds and support development project in rural areas. For the purpose of this study, however, attention is only directed to religious mahabers.

Religious belief systems have an immense influence in Ethiopian society, particularly in the Northern region. Christianity became Ethiopian official religion in the 4 th century. The Ethiopian Tewahedo Orthodox Church is one of the oldest religious institutions in the world. The tradition of mahabers is inherited from the Acts of Apostles. ${ }^{1}$ The twelve Apostles in Jerusalem gathered together to eat and drink in honour of saints. By doing so, the Apostles were also teaching religious ideas about the importance of

Refuge, Vol. 15, No. 3 (June 1996) 
"togetherness" and mutual assistance in the organization of community life. Hence the name of a mahaber is normally inherited from the church in the vicinity. For example, if the name of the church in the vicinity is St. George the group will be named after it.

A mahaber often consists of twelve members and one Muse (Moses) who acts as chairman. As the name implies, the title of Muse is derived from the biblical story about Moses, who organized his people to lead them out of misery from Egypt to Israel. In the same manner, the Muse is expected to think, feel and act like Moses. The functions are limited to prayers, eating and drinking, expression of primordial sentiments, social and political discussion and resolving disputes among members. There are no written rules that govern a mahaber organizations.

The event is hosted on a Saint's day, and there are about ten religious days in each month in Ethiopia. Each member hosts the mahaber at their homes on rotating basis. Members arrive in late afternoon. A priest opens the occasion with blessing; indeed, no ceremony takes place without his blessing. A loaf of bread is then cut and served, followed by food and drink. Members either depart late in the evening or stay the night; it depends on how elaborate a meal the person can afford.

Mahaber members visit each other in times of birth, christening, death and sickness. In rural areas members work together on each other's farm fields on rotating basis. If a member falls sick during planting or harvesting season, they help to plough or harvest the fields. In the cities, mahaber members contribute money if a fellow-member experiences difficulties. The social bond is so strong that a member cannot associate with the opponent of another member. Members of the same mahaber are not supposed to marry a widow or a divorcee of a fellow member.

Case Studies: Wegayehu's mahaber was created two years ago and has twelve members, four men and eight women. They came from Addis Ababa, and among them are people who were administrative staff at Ad- dis Ababa University, government officials, an ambassador and a retired Colonel in the Ethiopian army. The mahaber has a constitution that outlines the rules governing the conduct of members, the role and function of the organization. It gives the mahaber a life span of one year and as such is subject to revision each year. There is an elected chairman, a secretary, a treasurer, and a social committee devoted to preparing events for special occasions.

Desta's mahaber was established three years ago. It consists of six families and represents a typical traditional social setting. For instance, it does not penses in times of death or sickness of members, their families and close relatives. Members are also expected to contribute extra money for social functions in such times. Desta's mahaber rather holds an ita in conjunction with monthly gatherings on permanent basis. Decisions in relation to the ita or money aspect are totally controlled by men, while women control the organization of the mahaber's functions. In both mahabers' case, however, there are no rules or a wase (guarantor) requirement for a member who receives the ita money.

Newcomers to these mahabers are first introduced by a member. These

\section{In sum, mahabers constitute not only the religious aspects of Ethiopian culture but they are also an alternative means to create a traditional safety net in Canadian society that substitutes for broken family ties.}

have written rules whereby members only rely on such Ethiopian values and traditions as mutual trust, mutual aid, honesty and integrity. Members knew each other in Gondar, Ethiopia. Shared concerns about their children and their own social existence as a family unit constitute the most important aspects in their association. Members believe that the mahabers setting is an ideal social environment: it brings them together every month to exchange news and share ideas; children also go with their parents and "have fun." From the parents' point of view, the mahaber even represents a socializing agent for children about Ethiopian values and traditions.

Mahaber events are hosted on rotating basis among members but where to host it is left to the individual. For instance, on some occasions functions are held in restaurants. Members begin arriving in the afternoon. The ceremony in Admasu's mahaber opens with prayers; a loaf of bread is cut and served. Socializing, eating and drinking as well as the exchange of information and views follow.

Each member in both mahabers contributes $\$ 20$ to a common fund each month, which is used to cover ex- monthly events are highly regarded by every member as the only "moment" during which individuals are able to have an emotional and spiritual contact with the home country. Therefore, the screening process is important to select "like-minded" people, thereby avoiding controversies in later courses. In Desta's mahaber, members often remind each other of the social impact would have on their children. Perhaps that why these groups of families prefer married couples than single Ethiopians for association. Decisions regarding the organization of functions or any other issues related to membership concerns are made in the event setting. Mahabers create an ideal environment for direct member participation.

Both mahabers experience difficulty in maintaining a stable membership. Some people have left Desta's mahaber. Some people, particularly single men, find it difficult to host the event, that is understandable given the social pressure not to cancel an event devoted to honouring a Saint. One of the members who failed to show up on previous occasions had a hard time to explain how inconvenient it was for him to attend the mahaber; neverthe- 
less, after pressure by members he became willing to continue his membership. The mahaber had encountered similar difficulties before and almost dissolved following the absence of some members.

In sum, mahabers constitute not only the religious aspects of Ethiopian culture but they are also an alternative means to create a traditional safety net in Canadian society that substitutes for broken family ties. For instance, members visit each other in times of birth, christening, stress and sickness, including preparation of picnics and other special events. Getting together once a month and their common sentiments to share resources in times of "joy and sadness" gives social aspects of mahabers a legitimacy as equal as the aspect of religious devotion.

\section{Idirs 'Insurance'}

Membership in idir involves making money contributions to a common fund. According to Levine (1965) idirs originated from the Guraghe society in the 1930s and soon gained widespread popularity: "They are organized on a territorial basis, in villages, towns and city quarters; on an ethnic basis ... and even on an institutional basis as among employees of some government ministries" (p. 277). Other scholars like, Hoben (1973) and Messing (1985), consider idir as an Amharic tradition that was later adopted by other ethnic groups.

Idir money is dispensed to members in times of sickness, and loss of property due to accidents (fire and theft, for example). However, the central purpose of $i d i r$ is to cover funeral expenses since it is regarded by Ethiopians as more important than a wedding or other life experience. In urban Ethiopia, in particular, where only a few can afford to make prior arrangements for funeral expenses, and especially when there is no extended family, idir organizations provide an alternative support system.

At the time of a death of a member or his or her family or a relative all idir members are immediately informed. A cash payment is quickly made to the affected family, and members soon take command of the organization of functions (a member who fails to show up will be fined). A tent is erected and tables and chairs set at the home of the mourning member to receive those who come to pay their last respects. Food and drink is prepared. This function may last for few days.

Case Studies: This idir is organized around people who came from the Wello province for the purpose of helping each other through resource sharing and mutual emotional support. It consists of 20 members, with an almost equal number of men and women. Like iqubs and mahabers, the idir has a leadership composed of a chairman, secretary and a treasurer. It has also a guideline which outlines such rules and regulations as requiring members to attend all meetings, the amount of payments for the common fund and methods of payment, and ways of dispensing financial assistance to members in times of need. It prohibits members from bringing any agenda that relates to politics, religion and ethnicity (a member could have his or her own political leanings but cannot exercise it in the idir domain).

Members start gathering in the afternoon. Food and drink is served immediately. The rest of the time is devoted to social engagements. Near the end of the program formal discussions would resume, mainly devoted to presenting a financial report and making arrangements for the next meeting. There is a contribution of $\$ 20$ to a common fund. The money will be dispensed to members in such times of financial need as wedding, sickness, or death of a member's relative. There is also a subgroup within the idir that holds an ita every month. It amounts to $\$ 2000$, with each of the ten members contributing \$200. Low income and unemployed people are also encouraged to get involved. For example, four people can contribute $\$ 50$ each to own the ita; hence, both the ita money and the debt will be divided among them. There are no rules nor a guarantor or a signature. Ita allocation is based on need rather than a lottery system.
Most of the members had left their country when young and share common difficult experiences of life here in Canada and in other asylum countries. For this reason, there is a strong emotional attachment towards each other. Older people in the $i d i r$ provide a role model for young members. Those elders identify themselves socially and psychologically with others, and therefore, are highly respected by young people like Tekola. Tekola feels how comforting it is to ask advice and support from those members. He goes as far as to say that role models are needed in the community to help young people like him organize social life and develop a new identity.

Like iqubs and mahabers, a member first introduces the prospective member. The member promises to take responsibility should the would-be member fail to conform to the organization's norms and values. The wouldbe member will be given the idir's guideline. A committee composed of the chairman, secretary and treasurer, then screens the individual. If it is unable to reach a decision, the matter is referred to the general discussion. According to the chairman, this procedure is needed to screen out people who do not conform to the idir's values and principles. No doubt these sentiments are developed in response to widely prevalent perception that the Ethiopian community in Toronto has been politicised along ethnic/political lines.

\section{Implications for Adjustment}

Idirs, mahabers and iqubs create a social world for Ethiopians, one that exhibits who they are and enable them to express themselves. Ethiopian shared values and traditions, as well as shared experiences, such as discrimination in the host society, generate sentiments and perspectives that serve to hold individual Ethiopians together, and as a framework for social re-organization. Leadership roles, decision-making structures, communication or interaction patterns, and social control systems are defined to be compatible with their expressive behaviour. An exam- 
ple is the nature of idir, mahaber and iqub leadership, which is defined to play a social counselling and mediating role among its members and between a member and an outsider.

The idirs, mahabers and iqubs studied here have not been in existence for more than three years. Their members are drawn together more by friendship, shared experiences and concerns but less so by common origins of ethnicity; in fact, as far as I know none of the organizations is ethnically homogeneous. The Kidist Mariam mahaber consists of people with a middle class background. Idir and iqub members lived together as refugees in asylum countries. Desta's mahaber consists of families with children. There is one mahaber that has seven young women members, two of whom are single. The Meskel $^{2}$ Flower Cooperative Association was formed by the people who had lived in Greece as refugees.

Iqubs, mahabers and idirs by no means are to be viewed as sectarian organizations. The fact that their membership is composed of "like-minded" Ethiopians, and the fact that they are detached from the Ethiopian Association or other immigrant/refugee service agencies should not imply that they are a means to aggrandize self-serving purposes. Rather, such social organization formations would generate the dynamism that works towards creating an organic link between the individual Ethiopian and his or her Toronto community by encouraging the idea of solidarity and helping to develop a new vision of what life in Canada is and how it should be organized in the future.

The cultural linkage of iqubs, mahabers and idirs to those organizations that exist in Ethiopian societal environment is obvious, as evidenced by the similarity of how ceremonies proceed, the language of communication, mutual respect, recognition of elders, and the subordination of individual priorities to collective concerns in relation to organizational goals and objectives. It is also such cognitive orientation and common sentiments which constitute an important element of social solidar- ity and pave the way for the creation of those informal organizations.

Of importance is how iqubs, mahabers and idirs are suited to Ethiopian immigrants/refugees' capacity to direct and manage problems which would surface their in domains. Faceto-face interaction enables them to make decisions in the event setting, whereby every member then attempts to influence outcomes. The elected leadership have more responsibility than members, not more power. The strong emphasis on conforming to group values enables members to respond to each individual's behaviour. For example, a member who was involved in an altercation during an entertainment night might have to give an explanation about the incident and how he/she got implicated in it. While that person would likely be given the necessary support, but one cannot also rule out the chance of being subjected to a serious criticism about his or her behaviour.

Likewise, idirs, mahabers and iqubs' to proactively intervene in family disputes. It is common for an idir or mahaber to summon the spouses to the gatherings, and attempt to reconcile them. First there is a disapproval of both parties for quarrelling-implying that both have indeed violated family values and traditions; and then analysing the cause of the problems in the wider context. More often than not, the root cause is directed to the external environment: the acts of other people, the wider community, the wider society, etc., which enables the spouses to free from feeling shame and apprehension. Moreover, in the course of that event both the husband and wife will become active participants, not passive listeners, unlike a social worker advising the client.

Iqubs provide a means to mobilize financial resources within the Ethiopian community and to overcome economic problems. The rotating scheme of receiving the ita money, coupled with the absence of interest payments and collateral requirements, ensures accessibility for an average person. The social pressure not to default on payments when itas are held imposes saving discipline. Idirs and mahabers, on the other hand, are welfare organizations, more geared to addressing social problems. They provide a means for Ethiopians to come together and create a mutual support system: resolving domestic disputes, providing role models, preparing functions for new arrivals (a family or relative of a member), giving moral and financial support for sick and distressed individuals, etc. "Let us stay together in times of joy and sadness" is a common sentiment among members. Had the social aspect not been significant, there would be no purpose for the existence of idirs and mahabers, considering that Ethiopian immigrants and refugees have been able to access government social safety nets such as welfare and unemployment insurance. However, there is a difference between idirs and mahabers, precisely because the later remains to identify itself with religion. Ethiopians regard participation in mahabers as a religious as well as a social obligation. Nevertheless, religious values serve as social fabric to promote unity among Ethiopians; particularly, at a time when the psychology of many people in Toronto community is tainted by the perception of enduring political and ethnic differences.

Idirs, mahabers and iqubs strengthen Ethiopians' aspiration for self-sufficiency. Experience has taught Ethiopians that continued dependency on outside (government and nongovernmental) sources of assistance does not provide a secure command over the necessities of life in Canada. While many Ethiopians continue to depend on welfare and government housing programs, this dependancy in turn brings about frustration and has a demoralizing impact. Thus, pulling social and economic resources together helps attain self-reliance. In this light, idirs, mahabers and iqubs facilitate the process of reconstructing broken relationships or creating new ones, whereby such relationships lead to arrangements that complement the efforts of one individual against another, in order to act together as a cohesive 
social unit. Finally, idirs, mahabers and iqubs share common characteristics such as:

- Members define what their needs are and self-finance their own activities;

- Values and norms encourage solidarity

- Competition or intrigue for power are absent.

\section{Conclusion}

As recent arrivals in Canada, Ethiopians encounter a host of social and economic problems. The formation of iqubs, idirs and mahabers in the Ethiopian community in Toronto and Ottawa, signifies a response to these harsh social and economic realities. These organizations help mobilize social and economic resources within the Ethiopian community to overcome difficulties associated with settlement. Ethiopians shared experience of, for example, displacement, helplessness, dependency, loss of dignity and emotional deprivation, all are threads that hold individual Ethiopians together and sustain those social organizations.

The continued existence of iqubs, mahabers and idirs depends not only on the potency of Ethiopian values and traditions, but also on their long-term viability to provide support for members to attain their economic and spiritual and psychological and cultural needs. Hence, iqubs are viewed by members as a temporary self-help organization, that could be no longer needed once a member overcomes his or her financial difficulties. However, there is a strong social significance attached to mahabers and idirs. As people who came to Canada in their youth grow older, the meaning of social life becomes of paramount importance. The social environment in mahaber and idir settings enables parents and children to gather once a month where household conflicts and frustrations are resolved through the mediation of the members. This becomes imperative, for Ethiopian culture does not encourage an open discussion of family disputes, nor do Ethiopians rely on professional counsellors. In one Ethio- pian community workshop a woman denounced social workers for pushing spouses into adversarial positions and encourage separations, instead of reconciliation. More importantly, members visit each other in times of birth, christening, sickness and the death of a family of a member and this creates almost an extended family environment.

Finally, through engagement in a social setting Ethiopians construct a meaning out of their past and present experiences and develop a new vision of life in the host society. This is viewed as a positive trend for the Ethiopian community. Two interdependent and interrelated factors shape the relationship between individuals and their community: a community environment should help individuals fulfil their social and economic needs, spiritual/psychological satisfaction, and cultural entertainment; and secondly, there must be, among other things, respect for social opinions and compliance with commonly accepted standards.

Moreover, attitudes and patterns of interaction should be appropriate for social and economic exchange in a wider society (Thomas and Znaniecki 1958). It is at this point that one comes to appreciate the informal organizations in the Ethiopian community for their role as catalysts to re-organize the dispersed Ethiopian population, and to create the social and economic resources necessary for the formation of an "Ethiopian" community in the Canadian multicultural environment. In light of immigrant and refugee adjustment as a process of change and continuity in individual values and behaviour, the degree to which idirs, mahabers and iqubs are innovative and adaptive to Canadian socioeconomic and cultural environment will determine their long term viability as alternative support systems. A conventional view might attach a stigma to informal organizations as "backward" and view them as passive. Dynamic organizations, by contrast, have the capacity to continuously grow. Growth in turn leads to expan- sion-enlargement of the sphere of the organization, and necessitates a systematic management.

Before assessing whether mahabers, idirs and iqubs are dynamic, let us first understand why change in the organization is needed. At one point individuals' normal routine of behaviour and relationships could be affected by economic and social changes. For example, a new routine of work could affect the frequency of contact among individuals. The new arrangement, therefore, might force members of an organization to move away from direct participation and hand over task functions to elected individuals. For informal social organizations with a culture of non-hierarchical structure, "formalizing" the group occurs through the codification of rules and regulations to outline decision procedure and the terms and conditions for members to abide by such decisions.

In conclusion, informal social interaction and resource exchanges provide immigrants and refugees with an important support mechanism in their adjustment process. Adjustment is viewed as an incremental process of "getting used to living in Canadian society," which requires not only the skills and knowledge necessary to participate in Canadian economy, but also the existence of social organizations that provide a medium of cultural and spiritual expression.

\section{Notes}

1. Personal communication with LiqaeKahan Mesale Engda, Ethiopian Tewehado Orthodox Church in Toronto.

2. Meskel literally means the foundation of the Holy Cross, one of the many religious holidays in Ethiopia. It is celebrated on the 24th of September each year.

\section{Bibliography}

Berenback, Sahri, and Diego Guzman. 1992. The Solidarity Group Experience Worldwide. ACCION International, November.

Durkheim, Emile. 1993. The Division of Labour in Society. George Simpson (trans.). New York: The Free Press

Goldschmidt, Walter. 1959. Man's Way: A Preface to the Understanding of Human Society. New York: Holt. 
Hawley, Amos H. 1950. Human Ecology: A Theory of Community Structure. New York: The Ronald Press Co.

Hawley, Amos H. 1986. Human Ecology: A Theoretical Essay. Chicago: University of Chicago Press.

Health and Welfare Canada. 1988. After the Door Has Opened: Mental Health Issues Affecting Immigrants and Refugees in Canada. Canadian Task Force on Mental Health Issues Affecting Immigrants and Refugees.

Hoben, A. 1973. Land Tenure among the Amhara of Ethiopia: The Dynamic of Cognatic Descent. Chicago: University of Chicago Press.

Iacovetta, Franca. 1992. Such Hardworking People: Italian Immigrants in Postwar Toronto. Montreal \& Kingston: McGillQueen's University Press.

Indra, Doreen Marie. 1983. Social Science Research on South Asian Refugee Settlement in Canada. Edmonton, Alberta, Grant MacEwan Community College.

Isajiw, Wsevolod W. 1990. "Ethnic-Identity Retention." In Ethnic Identity and Equality: Varieties of Experience in a Canadian City. Toronto: University of Toronto Press.

Lanphier, Michael, and O. Lukomskyj. 1992. "Settlement Policies and Programmes." In Immigration and Refugee Policy: Australia and Canada Compared edited by Howard Adelman, Allan Borowski, Meyer Burstein, and Lois Foster. Toronto: University of Toronto Press.

Lanphier, Michael, and O. Lukomskyj. 1981. "Settlement Policies and Programmes" in Adelman, and others (ed.), Immigration and Refugee Policy: Australia and Canada Compared, Press.

Lefort, Rene. 1981. Ethiopia: An Heretical Revolution?. A.M. Berrett (Trans.). London: Zed Press.

Levine, Donald N. 1965. Wax and Gold: Tradition and Innovation in Ethiopian Culture. Chicago: The University of Chicago Press.

Levy, Ronald B. 1969. Human Relations: A Conceptual Approach. Scranton, Pennsylvania: International Textbook Company.

Minor, David W.1969. The Concept of Community. Chicago: Aldine.

Marx, Emanuel. 1990. "The Social World of Refugees: A Conceptual Framework." Journal of Refugee Studies, Vol. 3., No. 3.

Markakis, John, and Ayele Nega. 1986. Class and Revolution in Ethiopia. Trenton, New Jersey: Red Sea Press.

Messing, Simon D. 1985. Highland Plateau Amhara of Ethiopia, work edited by Lionel Bender (in 3 vols.). New Haven, CT.: Human relation Area Files, Inc.
Metaferia, Getachew, and Shifferaw Maigenet. 1991. The Ethiopian Revolution of 1974 and the Exodus of Ethiopia's Trained Human Resources. Lewiston: Edwin Mellen Press.

Morley, David. 1989. "Frameworks For Organizational Change: Towards Action Learning in Global Environments." In Learning Works: Searching For Organizational Futures, edited by Susan Wrigh and David Morley. Toronto: ABL Group, York University.

Moussa, Helene. 1994. "Sowing New Foundations: Refugee and Immigrant Women and Support Groups." Refuge, Canada Periodical on Refugees, Vol. 13, No. 9.

Moussa, Helene. 1993. Storm \& Sanctuary. The Journey of Ethiopian and Eritrean Women Refugees. Dundas, Ontario: Artemis Enterprises.

Opoku-Dapaah, Edward. 1993. Somali Refugee Community in Toronto: An Overview. Centre For Refugee Studies, York Lanes Press, York University.

Neuwirth, Gertrud. 1989. The Settlement of Ethiopian Refugees in Toronto: An Exploratory Study May.

Otero, Maria. 1986. The Solidarity Group Concept: Its Characteristics and Significance for Urban and Informal Sector Activities. PACT, January.

Pankhurst, Helene.1992. Gender, Development and Identity: An Ethiopian Study. London: Zed Books.

Report for a Series of Workshops, Ethiopian Association in Toronto, Inc., Toronto, December, 1993.

Rahmato, Desalegne. 1985. Agrarian Reform in Ethiopia. Trenton, New Jersey: Red See Press.

Romberg, Perry. 1994. "Service Delivery to Refugees and Immigrants: Towards an Integrated Approach." Refuge, Vol. 13, No. 9.

Sharma, Satya and Others (eds). 1991. Immigrants and Refugees in Canada: A national Perspective on Ethnicity, Multiculturalism and Cross-Cultural Adjustment. University of Saskatchewan, Saskatoon.

Tebeje, Ainalem. 1989. Cultural Interaction of Canadians and Ethiopian Newcomers in Canada, Employment and Immigration Canada.

Thomas, William T. and, Florian Znaniecki. 1958. The Polish Peasants in Europe and America. New York: Dover Publications.

UNHCR. 1993. The State of the World Refugees: the Challenge of Protection. New York: Penguin.

Yunus, Muhammad. 1983. Group-Based Savings and Credit For the Rural Poor. Chittagong University, November. $\square$
Refugee Rights Report on a Comparative Survey by

James C. Hathaway and John A. Dent

Toronto: York Lanes Press, 1995 , pp. 82. $\$ 11.95 \cdot$ ISBN 1-55014-266-6 Are visa controls intended to keep refugees from reaching an asylum country legal? Can asylum-seekers legitimately contest conditions of detention? At what point do refugees have the right to work, or to claim social assistance?

These are among the many issues addressed by Refugee Rights: Report on a Comparative Survey, a groundbreaking analysis of the human rights of refugees around the world. Working in collaboration with thirty renowned legal experts from Europe, Africa, Asia, Oceania, North America, and Latin America, Professor James Hathaway, Osgoode Hall Law School, York University, and John Dent, Refugee Law Unit, Centre for Refugee Studies, York University, analyze the international legal instruments that set the human rights of refugees. By grounding their analysis in real-life challenges facing refugees today, Hathaway and Dent have produced a book as valuable to activists as to scholars.

Refugee Rights will provoke debate on the adequacy of the international refugee rights regime. It is essential reading for everyone concerned to counter threats to the human dignity of refugees.

Avallable from:

York Lanes Press

Centre for Refuge Studies

York University

North York ON M3J 1P3

Fax: (416) 736-5837

email: refuge@yorku.ca 


\begin{tabular}{|c|c|c|c|c|c|c|c|c|c|c|c|}
\hline \multicolumn{12}{|c|}{$\begin{array}{c}\text { A Summary of Claims Processed by Immigration and Refugee Board } \\
\text { Processing Period: January-December, } 1995\end{array}$} \\
\hline & \multirow[b]{4}{*}{ Region } & \multicolumn{8}{|c|}{ By Processing Regions } & \multicolumn{2}{|c|}{ Pending } \\
\hline & & \multirow{3}{*}{$\begin{array}{l}\text { Claims } \\
\text { Referred }\end{array}$} & \multirow{3}{*}{$\begin{array}{l}\text { Heard } \\
\text { to } \\
\text { Completn }\end{array}$} & \multirow{3}{*}{$\begin{array}{l}\text { Other } \\
\text { Claims } \\
\text { Finalized }\end{array}$} & \multirow{2}{*}{\multicolumn{2}{|c|}{ Decisions }} & \multirow{3}{*}{$\begin{array}{c}\text { Percent } \\
\text { Accepted }\end{array}$} & \multicolumn{2}{|c|}{ Pending } & \multirow{3}{*}{$\begin{array}{l}\text { Claims } \\
\text { as \% of } \\
\text { Referred }\end{array}$} & \multirow{3}{*}{$\begin{array}{c}\text { Decision } \\
\text { as \% of } \\
\text { Decided }\end{array}$} \\
\hline & & & & & & & & Decisions & Claims & & \\
\hline & & & & & Positive & Negative & & Cusum & Cusum & & \\
\hline 1 & Ottawa/Atlantic & 978 & 698 & 109 & 585 & 115 & 83.6 & 53 & 912 & 93.3 & 7.6 \\
\hline 2 & Quebec & 12,689 & 5,340 & 1,300 & 3,482 & 1,545 & 69.3 & 545 & 13,186 & 103.9 & 10.8 \\
\hline 3 & Ontario I & 5,397 & 3,553 & 761 & 2,276 & 992 & 69.6 & 653 & 5,812 & 107.7 & 20.0 \\
\hline 4 & Ontario II & 5,160 & 3,483 & 826 & 2,287 & 1,197 & 65.6 & 434 & 4,189 & 81.2 & 12.5 \\
\hline 5 & Prairies & 431 & 386 & 46 & 322 & 60 & 84.3 & 18 & 331 & 76.8 & 4.7 \\
\hline \multirow[t]{2}{*}{6} & Vancouver & 1,417 & 935 & 437 & 662 & 187 & 78.0 & 209 & 1,964 & 138.6 & 24.6 \\
\hline & National Total & 26,072 & 14,395 & 3,479 & 9,614 & 4,096 & 70.1 & 1,912 & 26,394 & 101.2 & 13.9 \\
\hline \multicolumn{12}{|c|}{ By Major Source Countries } \\
\hline & \multirow[b]{3}{*}{ Nationality } & \multirow{3}{*}{$\begin{array}{l}\text { Claims } \\
\text { Referred }\end{array}$} & \multirow{3}{*}{\multicolumn{2}{|c|}{$\begin{array}{cc}\text { Heard } & \text { Other } \\
\text { to } & \text { Claims } \\
\text { Completn } & \text { Finalized }\end{array}$}} & & & & \multicolumn{2}{|c|}{ Pending } & \multirow{3}{*}{$\begin{array}{l}\text { Claims } \\
\text { as \% of } \\
\text { Referred }\end{array}$} & \multirow{3}{*}{$\begin{array}{l}\text { Decision } \\
\text { as \% of } \\
\text { Decided }\end{array}$} \\
\hline & & & & & Decis & ions & Percent & Decisions & Claims & & \\
\hline & & & & & Positive & Negative & Accepted & Cusum & Cusum & & \\
\hline 1 & Sri Lanka & 2,392 & 1,762 & 101 & 1,537 & 251 & 86.0 & 85 & 1,716 & 71.7 & 4.8 \\
\hline 2 & Iran & 1,901 & 1,113 & 143 & 882 & 202 & 81.4 & 116 & 1,925 & 101.3 & 10.7 \\
\hline 3 & Somalia & 1,655 & 1,370 & 125 & 1,210 & 29 & 97.7 & 122 & 1,570 & 94.9 & 9.8 \\
\hline 4 & Chile & 1,483 & 52 & 52 & 24 & 19 & 55.8 & 12 & 1,476 & 99.5 & 27.9 \\
\hline 5 & India & 1,259 & 815 & 311 & 492 & 263 & 65.2 & 149 & 1,489 & 118.3 & 19.7 \\
\hline 6 & Israel & 1,226 & 569 & 119 & 121 & 319 & 27.5 & 178 & 1,745 & 142.3 & 40.5 \\
\hline 7 & Venezuela & 1,071 & 252 & 85 & 142 & 69 & 67.3 & 46 & 1,217 & 113.6 & 21.8 \\
\hline 8 & Pakistan & 1,011 & 460 & 188 & 337 & 109 & 75.6 & 36 & 956 & 94.6 & 8.1 \\
\hline 9 & Bangladesh & 900 & 599 & 82 & 458 & 93 & 83.1 & 58 & 984 & 109.3 & 10.5 \\
\hline 10 & Algeria & 801 & 566 & 67 & 442 & 105 & 80.8 & 30 & 717 & 89.5 & 5.5 \\
\hline 11 & China & 777 & 309 & 239 & 141 & 167 & 45.8 & 72 & 729 & 93.8 & 23.4 \\
\hline 12 & Kazakhstan & 730 & 125 & 18 & 91 & 13 & 87.5 & 20 & 720 & 98.6 & 19.2 \\
\hline 13 & Zaire & 592 & 288 & 30 & 210 & 53 & 79.8 & 38 & 518 & 87.5 & 14.4 \\
\hline 14 & Romania & 575 & 380 & 104 & 120 & 260 & 31.6 & 57 & 602 & 104.7 & 15.0 \\
\hline 15 & Mexico & 548 & 102 & 102 & 40 & 65 & 38.1 & 15 & 568 & 103.6 & 14.3 \\
\hline 16 & Guatemala & 496 & 308 & 89 & 171 & 130 & 56.8 & 45 & 493 & 99.4 & 15.0 \\
\hline 17 & Afghanistan & 473 & 448 & 36 & 370 & 53 & 87.5 & 35 & 376 & 79.5 & 8.3 \\
\hline 18 & Russia & 445 & 236 & 77 & 176 & 59 & 74.9 & 33 & 507 & 113.9 & 14.0 \\
\hline 19 & El Salvador & 444 & 256 & 106 & 94 & 160 & 37.0 & 64 & 555 & 125.0 & 25.2 \\
\hline 20 & Lebanon & 434 & 235 & 69 & 112 & 106 & 51.4 & 56 & 549 & 126.5 & 25.7 \\
\hline 21 & Sudan & 429 & 276 & 39 & 251 & 14 & 94.7 & 16 & 303 & 70.6 & 6.0 \\
\hline 22 & Peru & 342 & 246 & 31 & 154 & 88 & 63.6 & 28 & 425 & 124.3 & 11.6 \\
\hline 23 & Iraq & 324 & 205 & 32 & 183 & 11 & 94.3 & 12 & 274 & 84.6 & 6.2 \\
\hline 24 & Nigeria & 322 & 196 & 46 & 113 & 76 & 59.8 & 30 & 297 & 92.2 & 15.9 \\
\hline 25 & Ukraine & 272 & 202 & 55 & 129 & 65 & 66.5 & 32 & 323 & 118.8 & 16.5 \\
\hline & 25 countries total & 20,902 & 11,370 & 2,346 & 8,000 & 2,779 & 74.2 & 1,385 & 21,034 & 100.6 & 12.8 \\
\hline & er countries & 5,170 & 3,025 & 1,133 & 1,614 & 1,317 & 55.1 & 527 & 5,360 & 103.7 & 18.0 \\
\hline Gra & Ind Totals & 26,072 & 14,395 & 3,479 & 9,614 & 4,096 & 70.1 & 1,912 & 26,394 & 101.2 & 13.9 \\
\hline & ms Referred are adj & then to & ke into acc & unt claims tr & ansferred & & & & & & \\
\hline & $\begin{array}{l}\text { isions Pending inclu } \\
\text { orting period (cumul } \\
\text { al Claims Pending ir } \\
\text { ated from Immigrati }\end{array}$ & tion and Refu & $\begin{array}{l}m \text { heard to co } \\
\text { total); Decid } \\
\text { claim referre } \\
\text { ugee Board St }\end{array}$ & $\begin{array}{l}\text { ed to the CRL } \\
\text { tatistical Sum }\end{array}$ & $\begin{array}{l}\text { Ice January } \\
\text { at a decisic } \\
\text { D, that ha } \\
\text { mary, April }\end{array}$ & $\begin{array}{l}1,1989 \text { for } w \\
n \text { has been } r \\
\text { ve not yet be }\end{array}$ & $\begin{array}{l}\text { hich no dec } \\
\text { made on the }\end{array}$ & $\begin{array}{l}\text { cision had be } \\
\text { claim. }\end{array}$ & een rende & by the en & did of the \\
\hline
\end{tabular}


Refuge

York Lanes Press

Centre for Refugee Studies

Suite 351, York Lanes

York University

4700 Keele Street, North York

Ontario, Canada M3J 1P3

Phone: (416) 736-5843

Fax: (416) 736-5837

Internet: refuge@yorku.ca

\section{GALL FOR PAPERS}

\section{REFUGEE CHILDREN}

The Centre for Refugee Studies will soon publish a special issue of Refuge on 'Refugee Children.' The issue will address to topics such as:

- The children in refugee camps

- The effects of political persecution and forced migration on refugee children

- Different approaches in the treatment of refugee children and their families

- Refugee children in the school system

- Exemplary local programs for refugee children and families

- Effect of Canadian regionalism on refugee resettlement

Papers are now being invited on these issues and other related areas for consideration.

Please send your contribution asap.

Articles may not exceed 16 pages (double-spaced) or about 4000 words. Short papers of about 900 words are also welcome. Word processed submissions may be sent in disc or by e-mail.

For further details, please contact:

Sabine Lübben, Guest Editor, Refuge Special Issue

Centre for Refugee Studies

York University, North York

Ontario, Canada M3J 1P3

Fax: (416) 736-5837- Tel: (416) 736-5663

Internet: slubben@yorku.ca 